\title{
Long-term outcome of inflammatory bowel disease patients with deep remission after discontinuation of TNF-blocking agents
}

\section{Molander, Pauliina}

2017

Molander , P , Farkkila , M , Kemppainen , H , Blomster , T , Jussila , A , Mustonen , H \& Sipponen , T 2017 , ' Long-term outcome of inflammatory bowel disease patients with deep remission after discontinuation of TNF-blocking agents ' , Scandinavian Journal of Gastroenterology , vol. 52 , no. 3 , pp. 284-290 . https://doi.org/10.1080/00365521.2016.1250942

http://hdl.handle.net/10138/311875

https://doi.org/10.1080/00365521.2016.1250942

unspecified

acceptedVersion

Downloaded from Helda, University of Helsinki institutional repository.

This is an electronic reprint of the original article.

This reprint may differ from the original in pagination and typographic detail.

Please cite the original version. 


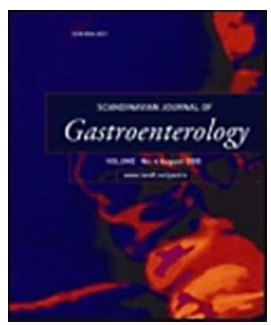

\section{LONG-TERM OUTCOME OF INFLAMMATORY BOWEL DISEASE PATIENTS WITH DEEP REMISSION AFTER DISCONTINUATION OF TNFa-BLOCKING AGENTS}

\begin{tabular}{|c|c|}
\hline Journal: & Scandinavian Journal of Gastroenterology \\
\hline Manuscript ID & Draft \\
\hline Manuscript Type: & Original Article \\
\hline Date Submitted by the Author: & $\mathrm{n} / \mathrm{a}$ \\
\hline Complete List of Authors: & $\begin{array}{l}\text { Molander, Pauliina; Helsinki University Central Hospital and University of } \\
\text { Helsinki, Peijas Hospital, Department of Gastroenterology } \\
\text { Färkkilä, Martti; Helsinki University Central Hospital and University of } \\
\text { Helsinki, Department of Gastroenterology } \\
\text { Kemppainen, Helena; Turku University Central Hospital, Department of } \\
\text { Gastroenterology } \\
\text { Blomster, Timo; Oulu University Central Hospital, Department of } \\
\text { Gastroenterology } \\
\text { Jussila, Airi; Tampereen yliopistollinen sairaala, Department of } \\
\text { Gastroenterology and Alimentary Tract Surgery } \\
\text { Mustonen, Harri; Helsinki University Central Hospital and University of } \\
\text { Helsinki, Department of Surgery } \\
\text { Sipponen, Taina; Helsinki University Central Hospital and University of } \\
\text { Helsinki, Department of Gastroenterology }\end{array}$ \\
\hline Keyword: & $\begin{array}{l}\text { Crohn's disease, Ulcerative colitis, Relapse, Withdrawal, TNFa-antagonist, } \\
\text { Infliximab, Adalimumab }\end{array}$ \\
\hline
\end{tabular}

\section{SCHOLARONE}

Manuscripts 


\title{
LONG-TERM OUTCOME OF INFLAMMATORY BOWEL DISEASE PATIENTS WITH DEEP REMISSION AFTER DISCONTINUATION OF TNFa-BLOCKING AGENTS
}

\author{
Authors: \\ Pauliina Molander ${ }^{1}$, Martti Färkkilä 1 , Helena Kemppainen 2, Timo Blomster ${ }^{3}$, Airi Jussila \\ 4, Harri Mustonen 5, Taina Sipponen 1
}

1 Department of Gastroenterology, Helsinki University Central Hospital and University of Helsinki, Helsinki, Finland

2 Turku University Central Hospital, Turku, Finland.

3 Oulu University Central Hospital, Oulu, Finland.

4 Department of Gastroenterology and Alimentary Tract Surgery, Tampere University Hospital, Tampere, Finland.

5 Department of Surgery, Helsinki University Central Hospital and University of Helsinki, Helsinki, Finland.

\section{Corresponding author:}

Pauliina Molander, M.D. PhD

Gastroenterology, Helsinki University Central Hospital, Peijas Hospital, Vantaa, Finland.

P.O.Box 900, FIN-00029, HUS, Finland.

e-mail: pauliina.molander@hus.fi.

Telephone number: +358 94711 


\title{
Key words:
}

Crohn's disease; ulcerative colitis; relapse; stopping; TNFa-antagonist; infliximab; adalimumab

\begin{abstract}
:
Background:

Little data exist on the long-term prognosis of patients with inflammatory bowel disease (IBD) after stopping TNFa- blocking therapy in deep remission. Existing data indicate that approximately $50 \%$ of patients on combination therapy who discontinued TNFa- blockers are still in remission 24 months later. The aims of this follow-up analysis was to evaluate the long-term remission rate after cessation of TNFa-blocking therapy, the predicting factors of a relapse and the response to restarting TNFa blockers.
\end{abstract}

\section{Methods:}

The first follow-up data of 51 IBD patients (17 Crohn's disease [CD], 30 ulcerative colitis [UC] and 4 inflammatory bowel disease type unclassified [IBDU]) in deep remission at the time of cessation of TNFa-blocking therapy have been published earlier. The long-term data was collected retrospectively after the first follow-up year to evaluate the remission rate and risk factors for the relapse after a median of 36 months.

\section{Results:}

After the first relapse-free year, 14 out of the remaining 34 IBD patients relapsed (41\%; $5 / 12$ [42\%] CD and 9/22 [41\%] UC/IBDU). Univariate analysis indicated no associations with any 
predictive factors. Re-treatment was effective in $90 \%(26 / 29)$ of patients.

\section{Conclusion:}

Of IBD patients in deep remission at the time of cessation of TNFa-blocking therapy, up to $60 \%$ experience a clinical or endoscopic relapse after a median follow-up time of 36 months (95\% Cl 31-41 months). No individual risk factors predicting relapse could be identified. However, the initial response to a restart of TNFa-blockers seems to be effective and well tolerated.

\section{INTRODUCTION}

The chronic nature of inflammatory bowel disease (IBD) and lack of recommendations for cessation of TNFa-blocking therapy may lead to long-term maintenance therapy with TNFa blockers as early treatment recommendations have become more widely accepted. With patients achieving remission, the potential severe side effects (i.e. infections, acute infusion reactions, delayed hypersensitivity reactions, risk of neoplasia, and safety issues during pregnancy) and economic issues prompt the questions on cessation of TNFablocking therapy. 1,2,3,4 In addition, it is nowise certain that the benefits of TNFa-blocking agents are permanent in the long run.

Several studies show that the overall risk of relapse after discontinuation of TNFa-blocking agents is $44 \%$ for Crohn's disease (CD, follow-up range of $6-125$ months) and $38 \%$ for ulcerative colitis (UC, follow-up range of 6-24 months). 5,6,7,8,9,10,11,12,13,14,15 The relapse risk seems to be lower in IBD patients who are in deep remission (clinical, biological and endoscopic remission) at the time of cessation of TNFa-blocking therapy 
compared to those in clinical remission only. ${ }^{9}$ Available data are insufficient for giving strong recommendations on at what point safely cease TNFa-blocking therapy. Therefore the decisions should be based on assessment of the patient's individual risks and benefits. In CD several factors have been investigated to identify patients who are more likely to achieve long-term remission after discontinuation of TNFa-blocking agents. The factors that have been associated with a higher risk of relapse are younger age, smoking, longer disease duration, fistulising phenotype, perianal disease, short duration of remission, previous surgical operation, endoscopically active disease, ileocolonic disease at diagnosis and previous TNFa-blocking therapy, high markers of inflammation and high infliximab trough level. On the other hand, mucosal healing, colonic CD, a shorter interval between disease diagnosis and starting anti-TNF, concomitant immunosupressive therapy and absence of antibodies to TNFa-blocking agents seem to decrease the risk of relapse after discontinuation of TNFa-blocking agents. $6,7,10,12,13,14,15,16$ A study by Waught and co-workers shows that $35 \%$ of the CD patients with a follow-up for nearly seven years after discontinuation of therapy remained in sustained clinical remission. No specific factor was associated with the duration of CD remission. ${ }^{17}$ In patients receiving TNFa-blocking agents for the prevention of post-operative CD recurrence, the risk of relapse after discontinuation is very high $(>75 \%)$ and the ceasing decision should be based on very good reasons. 18 Importantly, restarting of TNFa-blocking therapy for those who relapsed after stopping treatment seems to be effective and well-tolerated. 5,6,9,10,12

\footnotetext{
We have earlier published a prospectively collected 12-month data of cessation of TNFablocking therapy in IBD-patients with deep remission. ${ }^{9}$ The aim of this study was to evaluate the long-term relapse rate after the first year of follow-up and the predictive
} 
factors for relapse in this study population, as well as the response rate to TNFa-blocking agents after the restart of medication in the case of relapse.

\section{MATERIALS AND METHODS}

\section{Patients and study design}

All 51 IBD patients in this follow-up analysis were primarily recruited in a prospective multicenter study which was carried out at nine gastroenterological centers in Finland during the period from February 2010 to June 2013.9 At the time of inclusion all patients were in deep remission (i.e. clinical, endoscopic and faecal calprotectin -based [FC $<100 \mu \mathrm{g} / \mathrm{g}]$ remission). After the primary study, one UC patient was dropped from the follow-up due to no available data on a patients' report. Clinical notes of all enrolled patients were retrospectively reviewed for this long-term follow-up. All patients had an established IBD diagnosis, had received TNFa-blocking maintenance therapy for a minimum of one year (the median duration of infliximab [IFX] therapy was 13 [ $n=46$, range 11-77] months and adalimumab [ADA] therapy 27 [ $n=5$, range 16-36] months), had been in corticosteroid-free remission over a 6-months period prior to the inclusion, were in clinical, FC-based (FC $<100 \mu \mathrm{g} / \mathrm{g}$ ) and endoscopic remission at the time of inclusion. Due to its small size, the subgroup IBDU of four patients was combined with the UC group.

Given the retrospective design of this study, clinical disease activity was assessed by the physicians' global assessment (asymptomatic patients vs. symptomatic patients indicating active $(B D)$ in patients relapsing after the first year of follow-up and 12 months after the restart of TNFa-blocking therapy. At relapse endoscopic findings were scored, as in our earlier study ${ }^{9}$, according to the SES-CD 19 in CD and endoscopic Mayo score in UC and 
IBDU. 20 An SES-CD of 3-6 was defined as mildly active disease, 7-15 as moderately active disease, and $\geq 16$ as severely active disease. 21 Endoscopic Mayo subscore of $\geq 2$ defined active disease. 22

In a case of a clinical and/or endoscopic relapse after the first year of follow-up, TNFablocking therapy was restarted at the same dose and frequency as prior to withdrawal in exception of two patients, whose relapses were treated with oral corticosteroids or mesalazine. Ileocolonoscopy was performed 12 months after the restart of TNFa-blocking therapy in exception of four patients with normal fecal calprotectin levels. Endoscopic activity was defined as mild, moderate, or severe by an experienced gastroenterologist.

\section{Fecal calprotectin assays}

FC was measured using the quantitative enzyme immunoassay (the CALPRO尺 Calprotectin ELISA Test [ALP; Calpro AS, Lysaker, Norway]). The values quoted as normal were $<100 \mu \mathrm{g} / \mathrm{g} .23$

\section{Statistics}

The Statistical Package for the Social Sciences (SPSS version 23) for Windows software (SPSS, Chicago, IL, USA) was used for data analyses. Fisher's exact test was used to determine differences in binary variables. The significance was set at $p<0.05$ and twotailed tests were used. Kaplan-Meier survival analysis was employed in estimation of relapse-free survival rates, and the log-rank test was used to determine the differences between the groups. The Cox regression of proportional hazards was used to calculate univariate hazard ratios for categorical and continuous variables. The results were given as percentages, as median and range, or as mean and standard deviation (SD). 


\section{Ethical statement}

The study protocol and all documents of the prior prospective multicenter study were approved by the ethics committee at Helsinki University Hospital and at each participating university central hospital. Because this follow-up study was a retrospective reviewing of patients' medical records, no separate application for ethics committee was needed.

\section{RESULTS}

The baseline characteristics are described in Table 1. As established in earlier publication, during the first 12 -month follow-up, up to $33 \%$ of patients (5/17 [29\%] CD and $12 / 34$ [35\%]) UC/IBDU) in deep remission relapsed. 10 After the first relapse-free year, 14 of the remaining 34 IBD patients relapsed (40\%; 5/12 [42\%] CD and 9/22 [41\%] UC/IBDU) during median follow-up period of 36 months (1-69; in CD 38 months [3-68] and in UC 35 months [1-69]). Of the14 relapsed patients, endoscopic data were available on 13 at the time of a relapse. Out of five relapsed CD patients, one experienced a severe clinical relapse without endoscopic documentation, two experienced both clinical and endoscopic relapse (SES-CD 8 and10) and two experienced moderate endoscopic relapse without clinical symptoms mean (SES-CD 7 and 9). All UC patients experienced both clinical and endoscopic relapse (mean endoscopic Mayo score 2 [2-3]).

The time-to-relapse curves of all patients are shown in Figure 1. No significant difference was found in the relapse rate between CD and UC/IBDU, $p=0.919$.

\section{The risk factors for relapse}


Based on univariate analysis (Cox model) risk factors such as diagnosis, gender, disease duration, localization, behavior, smoking, family history, previous surgery, the TNFablocking agents used, concomitant medications or duration of the used TNFa-blocking agents were not associated with the risk of relapse, Table 2.

\section{Restarting TNFa-blocking therapy}

The response after restarting TNFa-blocking therapy was evaluated in all 29 of 51 IBD patients, Figure 2. The median time of follow-up after retreatment with TNFa-blocking agents was 12 (range 3-19) months. One relapsed UC patient was treated with corticosteroid and another with mesalazine instead of TNFa-blocking agents. After the restarting TNFa-blocking therapy, all except one UC patient achieved clinical remission or response at three months. During the follow-up period, three patients were operated on: one UC patient underwent colectomy less than two months after the restart of TNFablocking therapy due to nonresponse and another UC patient underwent colectomy after one year of TNFa-blocking therapy due to loss of response. Furthermore, one CD patient underwent ileo-ceacal resection after one year of TNFa-blocking therapy due to a symptomatic stricture. After a restart of IFX, two UC patients experienced an infusion reaction (one during the second IFX infusion without anti-drug antibody measurement and the other one six months after restarting developing anti-drug antibodies) and were treated with another TNFa-blocking agent. In addition, despite a combination therapy with thiopurins, three patients (one CD and two UC patient) developed low concentrations of anti-drug antibodies, but achieved a clinical response by dose escalation (one CD and one UC patient) or by switching to another TNFa-blocking agent (one UC patient). Twelve months after the restart of TNFa-blocking therapy 20 patients $(39 \% ; 8 \mathrm{CD}, 12 \mathrm{UC})$ were still in clinical remission. Six patients with CD and 11 patients with UC underwent a 12- 
month follow-up ileocolonoscopy, showing either endoscopic remission (4 CD, 9 UC) or mild activity ( $3 C D, 2 \cup C)$. The remaining three patients ( $2 C D, 1 \cup C$ ) had normal calprotectin levels serving as surrogate markers to endoscopic remission.

\section{DISCUSSION}

It is well known that TNFa-blocking therapy is effective in inducing and maintaining remission in IBD patients with moderate to severe CD and UC and therefore, for responders the long-term maintenance therapy is recommended. 24,25 However, life-long TNFa-blocking therapy in IBD patients in clinical remission or in deep remission is still questioned, since early treatment with an immunomodulator and/or TNFa-blocking agonist are nowadays recommended 26 and long-term safety issues are still debated.

According to this follow-up study almost $60 \%$ of patients relapsed after a median follow-up time of 36 months. No statistically significant difference in the relapse rates between CD and UC was found. Several studies, mainly with CD patients, have been published on the duration of remission after a discontinuation of TNFa-blocking therapy, and only few of these studies have assessed endoscopic activity during a long-term follow-up. It is interesting to note, that across all studies reporting on anti-TNF withdrawal of adult IBD patients in clinical remission, despite heterogeneous study designs and patient populations, the one and two -year relapse rates were reasonably consistent ranging from $21-39 \%$ and from $37 \%-56 \%$ respectively. $6,7,8,9,10,11,12,13$ These findings are in line with our results despite the fact that no baseline endoscopic remission was required in the majority of those earlier studies. However, recently published long-term data of the patients included in the STORI trial seem to indicate poorer remission rates after cessation 
of IFX for sustained remission: the vast majority of CD patients $(85 \%)$ had to restart the treatment over the course of time. 27 The longest follow-up periods reported are 10 years in $C^{14}$ and 7 years in UC. 15 Cumulative relapse rates in all studies rise over time.

Cessation of TNFa -blocking therapy may be considered for patients with a low relapse risk. The relapse risk may be minimized using predictors that identify those at a clinically meaningful risk of relapse. Achieving deep remission is currently considered to be the most important protective factor in disease relapse after TNFa -blocking therapy withdrawal. 28 Many of the risk factors shown in previous studies have been associated with incomplete remission with ongoing inflammatory disease activity at the time of discontinuation. It seems likely that not only the disease activity at the time of cessation of TNFa -blocking therapy but also previous disease history may have an impact on the risk of disease relapse following TNFa -blocking therapy withdrawal. Factors affecting the duration of a clinical remission after discontinuing anti-TNF therapy remain questionable even today. Moreover, it is very likely that patients' initial response to TNF $\alpha$-blocking therapy and tendency to maintain sustained remission after therapy withdrawal is based on a patient-unique genetic type of IBD disease.29,30 Future studies are needed to analyze the correlation of patients' genotype and the duration of remission after discontinued TNFa -blocking therapy. As clear and widely accepted recommendations for discontinuing TNF $\alpha$-blocking therapy are lacking, it has been stated that biological therapy should not be stopped in patients who have undergone multiple previous operations, demonstrated intolerance to conventional drugs or in whom the disease is difficult to control. 31 A multidisciplinary European expert panel (European Panel on the Appropriateness of Crohn's Disease Treatment II, EPACT-II) considered discontinuing TNFa-blocking therapy to be appropriate after four years, but also after two years if the 
patient was in deep remission. 32 The results of our previous study suggested that withdrawal of TNFa-blocking therapy after one year could be possible in IBD patients with deep remission as the duration of TNFa-blocking therapy did not influence the relapse risk over time. ${ }^{9}$ Nevertheless, considering the possible adverse events after stopping TNF $\alpha-$ blocking therapy, withdrawal should be considered carefully and discussed with the patient.

After a drug-holiday, the risk of immunization resulting in infusion reactions and loss of response should be considered. 33,34 Unfortunately, most of the studies report only shortterm outcomes and therefore more evidence is needed to demonstrate the real efficacy and safety of re-treatment. The studies including longer follow-up periods have reported remission rates from 80 to $92 \% .7,8$ These findings are in line with our study, all but one of the patients achieved clinical remission or response at three months and the remission rate at one year was considerably high (97\%). However, the risk of developing anti-drug antibodies may lead to infusion reaction and loss of response followed by severe problems. In our study, three patients underwent surgery due to no response to retreatment and five patients developed either anti-drug antibodies and/or experienced an infusion reaction. Taking this into account, withdrawal of TNFa-blocking therapy needs to be considered carefully.

Our study has some limitations. The patient group is limited and heterogeneous and the number of patients in the subgroups low. Moreover, cut-off levels used for endoscopic remission (SES-CD score and endoscopic Mayo score) may have allowed mild endoscopic activity at baseline and also during the follow-up. However, we consider that low baseline FC value as another criterion of remission ruled out patients with notable 
inflammatory activity. 35 Furthermore, clinical and endoscopic data after one year of stopping TNFa-blocking therapy was not collected for the study purpose. Therefore clinical scores were not available for all patients at the time of relapse and clinical and endoscopic scores were not available after the restart of TNFa-blocking therapy for all patients. However, the strength of this study is a long term surveillance after cessation of TNFablocking therapy in a clinical setting and endoscopic verification of a relapse.

The long-term follow-up demonstrates a fairly high relapse rate after cessation of TNFablocking therapy among IBD patients in deep remission. However, two out of five patients seem to remain in sustained clinical remission after cessation of TNFa-blocking therapy, but selecting these patients among potential relapsers is challenging. In relapsers, the response to a restart of TNF $\alpha$ antagonists seems to be effective and fairly well tolerated, even if the formation of anti-drug antibodies may result in to dose escalation or a change of TNFa-blocking agent. Therefore withdrawal of TNFa-blocking therapy should be considered carefully on individual bases.

\section{DISCLOSURES}

Statement of authorship: study design (PM, MF, TS), data collection (PM, HK, TB, AJ), statistical analysis (PM, HM), drafting the manuscript (PM, TS), final reading and approval of the manuscript (all authors).

PM received lecture fees from Abbvie, Ferring and MSD and consulting fees from Abbvie, MSD and Takeda. MF received consulting fees from MSD, Abbvie, Janssen, Orion Pharma, Medivir and Roche, and lecture fees from MSD, Abbvie, Bayer, Janssen and 
Tillots Pharma. TB received lecture fees from Abbvie and Tillotts Pharma and consulting fees from Abbvie. AJ received lecture fees from Abbvie, Ferring, MSD, Takeda and Tillotts Pharma and consulting fees from Abbvie, Hospira, MSD, Takeda and Tillotts Pharma. TS received lecture fees from Abbvie, AstraZeneca, Ferring, Medac, MSD, Pfizer, Tillots Pharma and Vifor Pharma and consulting fees from Hospira, Takeda, MSD and Tillotts Pharma. HK and HM declare no conflicts of interest.

\section{REFERENCES}

1. Lees CW, Ali Al, Thompson AI, Ho GT, Forsythe RO, Marquez L, Cochrane CJ, Aitken S, Fennell J, Rogers P, Shand AG, Penman ID, Palmer KR, Wilson DC, Arnott ID, Satsangi J. The safety profile of anti-tumor necrosis factor therapy in inflammatory bowel disease in clinical practice: analysis of 620 patient-year follow-up. Aliment Pharmacol Ther 2009;29:286-97.

2. Siegel CA, Marden SM, Persing SM, Larson RJ, Sands BE. Risk of lymphoma associated with combination anti-tumor necrosis factor and immunomodulator therapy for the treatment of Crohn's disease: a meta-analysis. Clin Gastroenterol Hepatol 2009;7:874-81.

3. Bewtra M, Lewis JD. Update on the risk of lymphoma following immunosuppressive therapy for inflammatory bowel disease. Expert Rev Clin Immunol 2010;6:621-31.

4. Schnitzler F, Fidder H, Ferrante M, Ballet V, Noman M, Van Assche G, Spitz B, Hoffman I, Van Steen K, Vermeire S, Rutgeerts P. Outcome of pregnancy in women with inflammatory bowel disease treated with antitumor necrosis factor therapy. Inflamm Bowel Dis $2011 ; 17: 1846-54$. 
5. Molnar T, Lakatos PL, Farkas K, Nagy F, Szepes Z, Miheller P, Horváth G, Papp M, Palatka K, Nyári T, Bálint A, Lőrinczy K, Wittmann T. Predictors of relapse in patients with Crohn's disease in remission after 1 year of biological therapy. Aliment Pharmacol Ther 2013;37:225-33.

6. Louis E, Mary JY, Vernier-Massouille G, Grimaud JC, Bouhnik Y, Laharie D, Dupas JL, Pillant H, Picon L, Veyrac M, Flamant M, Savoye G, Jian R, Devos M, Porcher R, Paintaud G, Piver E, Colombel JF, Lemann M; Groupe D'etudes Thérapeutiques Des Affections Inflammatoires Digestives. Maintenance of remission among patients with Crohn's disease on anti-metabolite therapy after infliximab therapy is stopped. Gastroenterology 2012;142:63-70.

7. Brooks AJ, Sebastian S, Cross SS, Robinson K, Warren L, Wright A, Marsh AM, Tsai H, Majeed F, McAlindon ME, Preston C, Hamlin PJ, Lobo AJ. Outcome of elective withdrawal of antitumour necrosis factor-a therapy in patients with Crohn's disease in established remission. J Crohns Colitis 2015; Epub ahead of print

8. Steenholdt C, Molazahi A, Ainsworth MA, Brynskov J, Østergaard, Thomsen O.

Outcome after discontinuation of infliximab in patients with inflammatory bowel disease in clinical remission: an observational Danish single center study. Scand J Gastroenterol 2012;47:518-27.

9. Molander P, Färkkilä M, Salminen K, Kemppainen H, Blomster T, Koskela R, Jussila A, Rautiainen H, Nissinen M, Haapamäki J, Arkkila P, Nieminen U, Kuisma J, Punkkinen J, Kolho KL, Mustonen $\mathrm{H}$, Sipponen T. Outcome after discontinuation of TNFalpha-blocking therapy in patients with inflammatory bowel disease in deep remission. Inflamm Bowel Dis 2014;20:1021-8.

10. Kennedy NA, Warner B, Johnston EL, Flanders L, Hendy P, Ding NS, Harris R, Fadra AS, Basquill C, Lamb CA, Cameron FL, Murray CD, Parkes M, Gooding I, Ahmad T, Gaya 
DR, Mann S, Lindsay JO, Gordon J, Satsangi J, Hart A, McCartney S, Irving P; UK AntiTNF withdrawal study group, Lees CW. Relapse after withdrawal from anti-TNF therapy for inflammatory bowel disease: an observational study, plus systematic review and metaanalysis. Aliment Pharmacol Ther 2016; doi: 10.1111/apt.13547. Epub ahead of print. 11. Gisbert JP, Alicia C Marín AC, Chaparro M. The Risk of Relapse after Anti-TNF Discontinuation in Inflammatory Bowel Disease: Systematic Review and Meta-Analysis. Am J Gastroenterol 2016;111:632-47.

12. Torres J, Boyapati RK, Kennedy N, Louis E, Colombel J-F, Satsangi J. Systematic Review of Effects of Withdrawal of Immunomodulators or Biologic Agents From Patients with Inflammatory Bowel Disease. Gastroenterology 2015;149:1716-30.

13. Bortlik M, Duricova D, Machkova N, Bortlik M, Duricova D, Machkova N.

Discontinuation of anti-tumor necrosis factor therapy in inflammatory bowel disease patients: a prospective observation. Scand J Gastroenterol 2016;2:196-202.

14. Baert F, Drobne D, Gils A, Vande Casteele N, Hauenstein S, Singh S, Lockton S, Rutgeerts P, Vermeire S. Early trough levels and antibodies to infliximab predict safety and success of reinitiation of infliximab therapy. Clin Gastroenterol Hepatol 2014;12:1474-81. 15. Rismo R, Olsen T, Cui G, Paulssen EJ, Christiansen I, Johnsen K, Florholmen J, Goll R. Normalization of mucosal cytokine gene expression levels predicts long-term remission after discontinuation of anti-TNF therapy in Crohn's disease. Scand J Gastroenterol 2013;48:311-9.

16. Papamichael K, Vande Casteele N, Gils A, Tops S, Hauenstein S, Singh S, Princen F, Van Assche G, Rutgeerts P, Vermeire S, Ferrante M. Long-Term Outcome of Patients With Crohn's Disease Who Discontinued Infliximab Therapy Upon Clinical Remission. Clin Gastroenterol Hepatol 2015;13:1103-10. 
17. Waugh AW, Garg S, Matic K, Gramlich L, Wong C, Sadowski DC, Millan M, Bailey R, Todoruk D, Cherry R, Teshima CW, Dieleman L, Fedorak RN. Maintenance of clinical benefit in Crohn's disease patients after discontinuation of infliximab: long-term follow-up of a single centre cohort. Aliment Pharmacol Ther 2010;32:1129-34.

18. De Cruz P, Kamm MA, Prideaux L, Allen PB, Desmond PV. Postoperative recurrent luminal Crohn's disease: a systematic review. Inflamm Bowel Dis 2012;18(4):758-77. 19. Daperno M, D’Haens G, Van Assche G, Baert F, Bulois P, Maunoury V, Sostegni R, Rocca R, Pera A, Gevers A, Mary JY, Colombel JF, Rutgeerts P. Development and validation of a new, simplified endoscopic activity score for Crohn's disease: the SES-CD. Gastrointest Endosc 2004;60:505-12.

20. Schroeder KW, Tremaine WJ, Ilstrup DM. Coated oral 5-aminosalicylic acid therapy for mildly to moderately active ulcerative colitis. N Engl J Med 1987;317:1625-9.

21. Moskovitz DN, Daperno M, Van Assche G. Defining and validating cut-offs for the Simple Endocopic Score for Crohn's Disease. Gastroenterology 2007;132:S1097.

22. D'Haens G, Sandborn WJ, Feagan BG, Geboes K, Hanauer SB, Irvine EJ, Lémann M, Marteau P, Rutgeerts P, Schölmerich J, Sutherland LR. A review of activity indices and efficacy end points for clinical trials of medical therapy in adults with ulcerative colitis. Gastroenterology 2007;132: 763-86.

23. Schnitzler F, Fidder H, Ferrante M, Noman M, Arijs I, Van Assche G, Hoffman I, Van Steen K, Vermeire S, Rutgeerts P. Mucosal healing predicts long-term outcome of maintenance therapy with infliximab in Crohn's disease. Inflamm Bowel Dis 2009;15:12951301.

24. Dignass A, Van Assche G, Lindsay JO, Lémann M, Söderholm J, Colombel JF, Danese S, D'Hoore A, Gassull M, Gomollón F, Hommes DW, Michetti P, O'Morain C, Oresland T, Windsor A, Stange EF, Travis SP; European Crohn's and Colitis Organisation 
(ECCO). The second European evidence-based consensus on the diagnosis and managementof Crohn's disease: current management. J Crohns Colitis 2010;4:28-62.

25. D'Haens GR, Panaccione R, Higgins PD, Vermeire S, Gassull M, Chowers Y, Hanauer SB, Herfarth H, Hommes DW, Kamm M, Löfberg R, Quary A, Sands B, Sood A, Watermeyer G, Lashner B, Lémann M, Plevy S, Reinisch W, Schreiber S, Siegel C, Targan S, Watanabe M, Feagan B, Sandborn WJ, Colombel JF, Travis. The London Position Statement of the World Congress of Gastroenterology on Biological Therapy for IBD with the European Crohn's and Colitis Organization: when to start, when to stop, which drug to choose, and how to predict response? Am J Gastroenterol 2011;106:199_ 21.

26. Pariente B, Cosnes J, Danese S, Sandborn WJ, Lewin M, Fletcher JG, Chowers Y, D'Haens G, Feagan BG, Hibi T, Hommes DW, Irvine EJ, Kamm MA, Loftus EV Jr, Louis E, Michetti P, Munkholm P, Oresland T, Panés J, Peyrin-Biroulet L, Reinisch W, Sands BE, Schoelmerich J, Schreiber S, Tilg H, Travis S, van Assche G, Vecchi M, Mary JY, Colombel JF, Lémann M. Development of the Crohn's disease digestive damage score, the Lémann score. Inflamm Bowel Dis 2011;17:1415-22.

27. Reenaers C, Nachury M, Bouhnik Y, Laharie D, Allez M, Dupas JL, Amiot A, Savoye G, Altwegg R, Devos M, Malamut G, Bourreille A, Flourie B, Marteau P, Vuitton L, Coffin B, Viennot S, Colombel JF, Mary JY, Louis E, on behalf of GETAID . Long-term outcome after infliximab withdrawal for sustained remission in Crohn's disease. UEG Journal 2015; October 2015; 3 (5 suppl) A31.

28. Pariente B, Laharie D. Review article: why, when and how to de-escalate therapy in inflammatory bowel diseases. Aliment Pharmacol Ther 2014;40:338-53.

29. Parkes M, Barrett JC, Prescott NJ, Tremelling M, Anderson CA, Fisher SA, Roberts RG, Nimmo ER, Cummings FR, Soars D, Drummond H, Lees CW, Khawaja SA, Bagnall 
R, Burke DA, Todhunter CE, Ahmad T, Onnie CM, McArdle W, Strachan D, Bethel G, Bryan C, Lewis CM, Deloukas P, Forbes A, Sanderson J, Jewell DP, Satsangi J, Mansfield JC; Wellcome Trust Case Control Consortium, Cardon L, Mathew CG. Sequence variants in the autophagy gene IRGM and multiple other replicating loci contribute to Crohn's disease susceptibility. Nat Genet 2007;39:830-2.

30. Arijs I, Li K, Toedter G, Quintens R, Van Lommel L, Van Steen K, Leemans P, De Hertogh G, Lemaire K, Ferrante M, Schnitzler F, Thorrez L, Ma K, Song XY, Marano C, Van Assche G, Vermeire S, Geboes K, Schuit F, Baribaud F, Rutgeerts P. Mucosal gene signatures to predict response to infliximab in patients with ulcerative colitis. Gut 2009;58:1612-9.

31. Kamm MA, Ng SC, De Cruz P, Allen P, Hanauer SB. Practical application of anti-TNF therapy for luminal Crohn's disease. Inflamm Bowel Dis 2011;17:2366-91.

32. Pittet V, Froehlich F, Maillard MH, Mottet C, Gonvers JJ, Felley C, Vader JP, Burnand B, Michetti P, Schoepfer A; EPACT-II Update Panellists. When do we dare to stop biological or immunomodulatory therapy for Crohn's disease? Results of a multidisciplinary European expert panel. J Crohns Colitis 2013;7:820-6.

33. Farrell RJ, Alsahli L, Jeen YT, Falchuk KR, Peppercorn MA, Michetti P. Hydrocortisone intravenous premedication reduces antibodies to infliximab in Crohn's disease: a randomized controlled trial. Gastroenterology 2003;124:917-24.

34. Steenholdt C. Svenson M, Bendtzen K, Thomsen O. $\varnothing$, Brynskov J, Ainsworth M. A. Severe infusion reactions to infliximab: aetiology, immunogenicity and risk factors in patients with inflammatory bowel disease. Aliment Pharmacol Ther 2011;34: 51-8. 35. Røseth AG, Aadland E, Grzyb K. Normalization of faecal calprotectin: a predictor of mucosal healing in patients with inflammatory bowel disease. Scand J Gastroenterol 2004;39:1017-20. 
A.

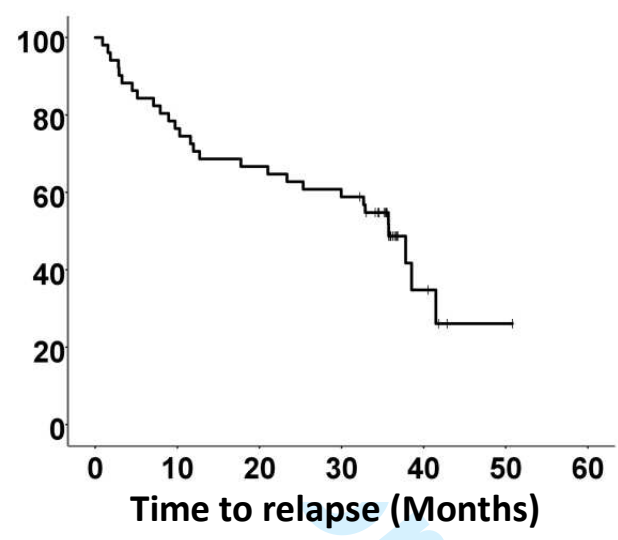

B.

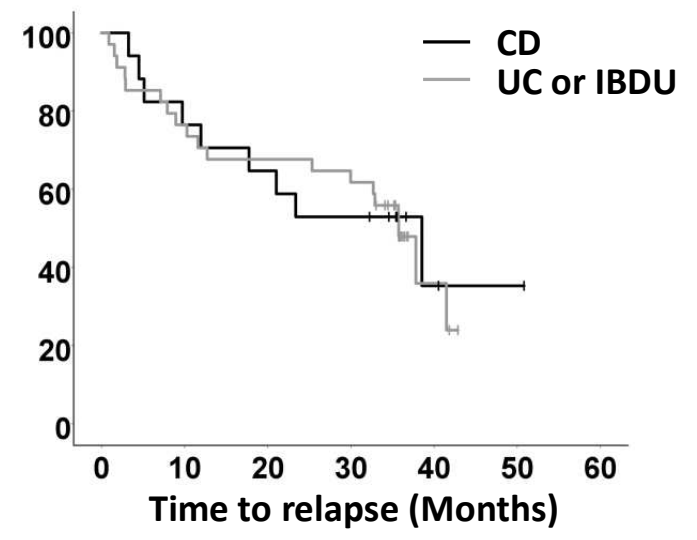




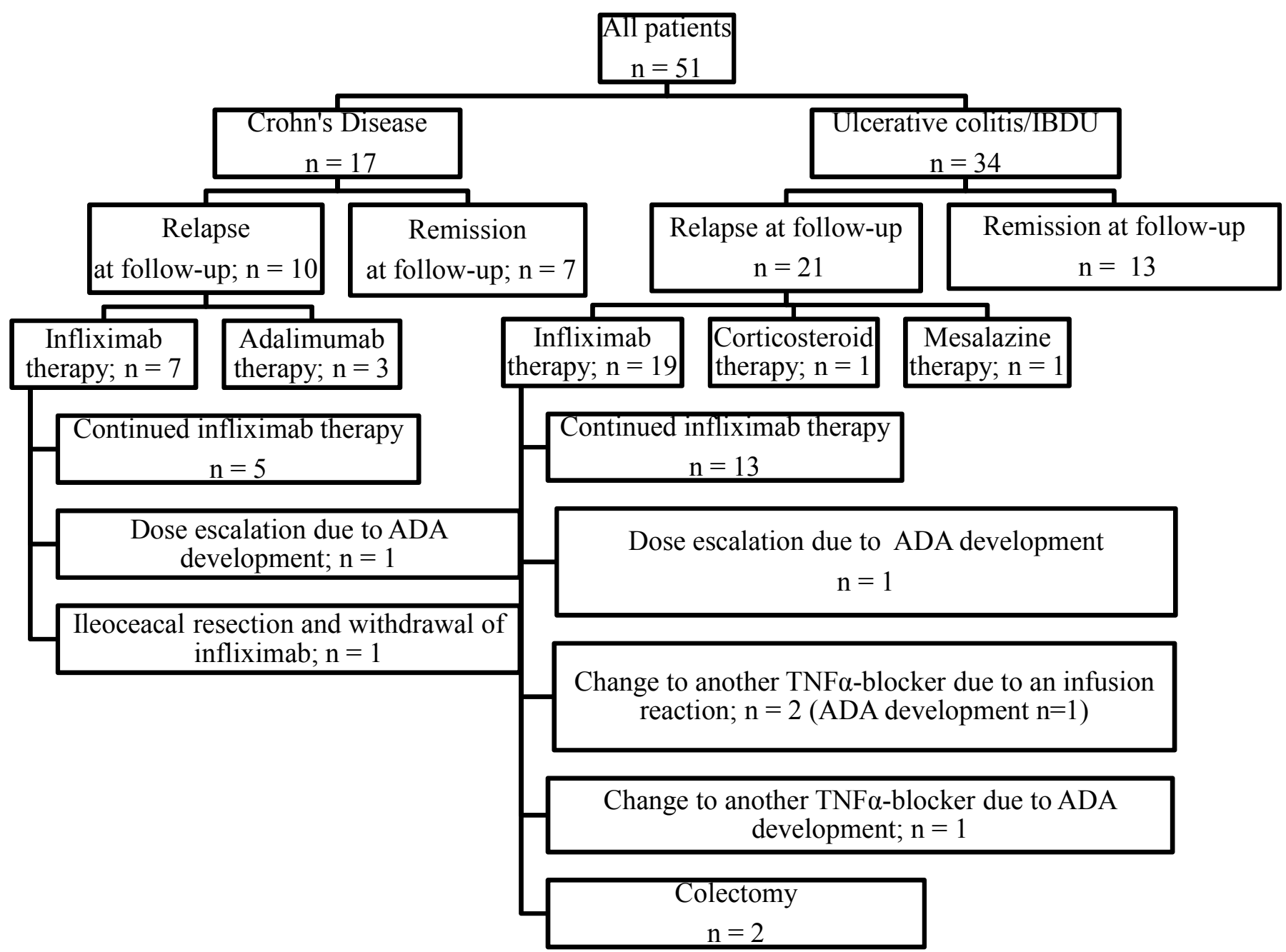

ADA; anti-drug antibody 
Table 1. Patients' clinical and demographic characteristics at baseline.

\begin{tabular}{|c|c|c|}
\hline & $\begin{array}{l}\text { Ulcerative colitis/ } \\
\text { Inflammatory } \\
\text { bowel disease } \\
\text { unclassified } \\
\mathrm{n}=34\end{array}$ & $\begin{array}{l}\text { Crohn's disease } \\
n=17\end{array}$ \\
\hline Male/Female & $19 / 15$ & $8 / 9$ \\
\hline Age at onset (median, range) & $26(8-45)$ & $23(13-42)$ \\
\hline Age at induction (median, range) & $32(13-58)$ & $33(15-52)$ \\
\hline Active smoker, $\mathrm{n}(\%)$ & $4 \quad(12)$ & $4 \quad(24)$ \\
\hline Disease duration (median, range) & $6 \quad(1-35)$ & $10(3-26)$ \\
\hline Previous bowel surgery, $\mathrm{n}(\%)$ & & $8 \quad(47)$ \\
\hline $\begin{array}{l}\text { Disease behavior (Mb Crohn), } \mathbf{n}(\%) \\
\text { Inflammatory (B1) } \\
\text { Stricturing (B2) } \\
\text { Penetrating (B3) } \\
\text { B1 } \pm \text { perianal disease } \\
\text { B2 } \pm \text { perianal disease } \\
\text { B3 } \pm \text { perianal disease }\end{array}$ & & $\begin{array}{ll}11 & (65) \\
4 & (24) \\
1 & (6) \\
0 & \\
1 & (6) \\
0 & \end{array}$ \\
\hline Disease location & $\begin{array}{lr}\text { Proctitis } & 0 \\
\text { Left colon } & 14 \\
\text { Extensive colitis } & 20\end{array}$ & $\begin{array}{lc}\text { Ileum (L1) } & 1 \\
\text { Colon (L2) } & 4 \\
\text { Ileocolon (L3) } & 12\end{array}$ \\
\hline $\begin{array}{l}\text { Concomitant medications, } \mathrm{n}(\%) \\
\text { No concomitant medications } \\
\text { Mesalazine } \\
\text { Azathioprine/6-MP } \\
\text { Azathioprine/6-MP+ mesalazine } \\
\text { Methotrexate + mesalazine }\end{array}$ & $\begin{array}{ll}1 & (3) \\
4 & (12) \\
12 & (35) \\
17 & (50)\end{array}$ & $\begin{array}{ll}1 & (6) \\
3 & (18) \\
7 & (41) \\
5 & (29) \\
1 & (6)\end{array}$ \\
\hline $\begin{array}{l}\text { Duration of TNFa-blocking therapy } \\
\text { prior to cessation of therapy (months) } \\
\text { Infliximab (median, range) } \\
\text { Adalimumab (median, range) }\end{array}$ & $14(11-78)$ & $\begin{array}{l}32(11-72) \\
26(16-36)\end{array}$ \\
\hline $\begin{array}{l}\text { TNFa-blocking therapy, n (\%) } \\
\text { Infliximab } \\
\text { Adalimumab }\end{array}$ & $34(100)$ & $\begin{array}{ll}12 & (71) \\
5 & (29)\end{array}$ \\
\hline
\end{tabular}

6-MP = 6-Mercaptopurine 
Table 2. Predictors for disease relapse in the study population.

\begin{tabular}{|c|c|c|c|c|}
\hline Variable & P-value & $\begin{array}{r}\text { Hazard } \\
\text { Ratio }\end{array}$ & $\begin{array}{r}95 \% \mathrm{Cl} \\
\text { lower }\end{array}$ & upper \\
\hline Diagnosis; CD versus UC/IBDU & 0.919 & 1.042 & 0.469 & 2.316 \\
\hline Male sex & 0.780 & 0.899 & 0.425 & 1.899 \\
\hline Age at diagnosis & 0.341 & 0.977 & 0.931 & 1.025 \\
\hline Age at diagnosis; $<25$ y versus $\geq 25 y$ & 0.073 & 0.492 & 0.227 & 0.069 \\
\hline Age at diagnosis; $<20$ y versus $\geq 20 y$ & 0.090 & 0.508 & 0.232 & 1.112 \\
\hline Localisation of CU & 0.280 & 1.704 & 0.648 & 4.483 \\
\hline Localisation of CD & 0.345 & 1.000 & & \\
\hline L3 versus L1 & 0.243 & 3.888 & 0.398 & 38.017 \\
\hline L3 versus $L 2$ & 0.464 & 0.453 & 0.054 & 3.778 \\
\hline Disease behavior (CD) & 0.995 & 1.000 & & \\
\hline $\mathrm{B} 1$ versus $\mathrm{B} 2$ & 0.793 & 0.802 & 0.154 & 4.177 \\
\hline$B 1$ versus $B 3$ & 0.995 & 1.008 & 0.107 & 9.470 \\
\hline$B 1$ versus $B 2+$ perianal disease & 0.242 & 2.391 & 0.555 & 10.298 \\
\hline Smoking & 0.252 & 1.000 & & \\
\hline No versus $<10$ cigarretts / day & 0.125 & 0.383 & 0.112 & 1.306 \\
\hline No versus smoker & 0.356 & 0.644 & 0.253 & 1.640 \\
\hline No versus smoker or previous smoker & 0.117 & 0.524 & 0.233 & 1.177 \\
\hline Age at induction & 0.375 & 0.981 & 0.941 & 1.023 \\
\hline Age at induction; $<30$ versus $\geq 30-40$ & 0.361 & 0.662 & 0.273 & 1.605 \\
\hline Age at induction; $<30$ versus $\geq 41$ & 0.927 & 0.956 & 0.362 & 2.526 \\
\hline Duration of the disease at induction & 0.974 & 1.001 & 0.949 & 1.055 \\
\hline Duration of the disease; $>5-10$ years & 0.173 & 1.876 & 0.760 & 4.630 \\
\hline Duration of the disease; $\geq 11$ years & 0.447 & 1.451 & 0.556 & 3.784 \\
\hline Previous surgery & 0.577 & 0.739 & 0.255 & 2.140 \\
\hline Positive family history & 0.791 & 0.876 & 0.331 & 2.324 \\
\hline TNF a-blocking therapy used; IFX vs. ADA & 0.573 & 1.418 & 0.421 & 4.782 \\
\hline Duration of the TNFa-blocking therapy; median & 0.995 & 1.000 & 0.977 & 1.024 \\
\hline CRP at discontinuation; median & 0.450 & 0.935 & 0.785 & 1.113 \\
\hline Hemoglobin at discontinuation; median & 0.434 & 1.010 & 0.985 & 1.036 \\
\hline
\end{tabular}

